\title{
EFFECT OF PENTOXIFYLLINE ON ACETAMINOPHEN- INDUCED HEPATOTOXICITY IN ALBINO MICE
}

\author{
$B \mathcal{Y}$ \\ Somaia A. Mokbel \\ Clinical Pharmacology Departinent, Faculty of Medicine, \\ Mansoura University, Egypt
}

\begin{abstract}
The present work was conducted to evaluate the possible protective effect of pentoxifylline (PTX) in comparison to $\mathrm{N}$-acetyl-cysteine (NAC) on the hepatotoxicity-induced by acetaminophen (AP) in mice. Furthermore, this study aimed at declaring the effect of PTX on oxidative stress and tumor necrosis factor-alpha $(T N F-\alpha)$ in this model. The current work was carried out on 36 healthy male mice weighing (25-30 grams), the animals were divided into 6 equal groups; Group (I), received intra-peritoneal (IP) single dose of normal saline $(0.5 \mathrm{ml})$, group $(I I)$, received $N A C$ in a single dose of $150 \mathrm{mg} / \mathrm{kg}, I P$, Group (III), received PTX in a single dose of $100 \mathrm{mg} / \mathrm{kg}, I P$. Group (IV), received AP in a single dose of $900 \mathrm{mg} /$ $\mathrm{kg}, I P ;$ group $(V)$ received once administration of $N A C(150 \mathrm{mg} / \mathrm{kg}, 30$ minutes before once injection of $900 \mathrm{mg} / \mathrm{kg}$ AP, IP), group (VI), received once administration of PTX in a dose of I00mg/kg, IP, $30 \mathrm{~min}$ utes before IP once injection of $900 \mathrm{mg} / \mathrm{kg} \mathrm{AP)}$. Serum alanine aminotransferase (ALT), serum TNF- $\alpha$, hepatic tissue malondialdehyde (MDA) and hepatic tissue calcium were significantly elevated after 4 hours of AP administration in comparison to control groups. These changes were nearly reversed by pretreatment with either NAC or PTX. This improvement of the results may be due to high efficacy of NAC and PTX as antioxidant and anti-TNF- $\alpha$.
\end{abstract}

\section{INTRODUCTION}

Acetaminophen is a commonly used analgesic and antipyretic drug, however, when used in high doses, it causes fulminant hepatic necrosis and nephrotoxic effects in humans and experimental animals (Sener et al., 2003). The biochemical mechanism by which AP-induced liver injury has been elucidated in details and is believed to be the result of meta- bolic conversion of AP to a highly reactive intermediate, namely; $\mathrm{N}$-acetyl-Pbenzoquinonimine (NAPQI) by cytochrome $\mathrm{P}_{450}$ mediated mixed function oxidases; this metabolite is known to be detoxified by glutathione (Dambach et al., 2006).

Lipid peroxidation mediated by oxygen free radicals is believed to be an important cause of destruction and damage to cell 
membranes and attention has been focused on the role of reactive oxygen species in mediating the micro-vascular disturbances that precede tissue damage induced by various chemicals (Mah et al., 1993 and Krahauer, 2000).

Pentoxifylline (PTX) has been used in the treatment of peripheral vascular diseases because of its potent effect on flexibility of erythrocytes and reduction of platelet aggregation (Gomez-Cambronero et al., 2000). Subsequently, PTX was found to have anti-inflammatory properties mediated via inhibition of phosphodiesterase (Semmler et al., 1993). In vitro data suggest that PTX may posse anti- (TNF- $\alpha$ ) properties (Maksymowych et al., 1995). Furthermore, PTX inhibits lipopolysaccharide-induced production of TNF- $\alpha$ by monocytes (Gomez-Cambronero et al., 2000).

$\mathrm{N}$-acetyl cysteine (NAC) is a well known antioxidant prevented AP- induced depletion of glutathione and superoxide dismutase as well as hepatotoxicity. NAC also abrogated transcription factors including nuclear factor Kappa-B (NF-kB) which regulate the production of inflammatory mediators implicated in hepatotoxicity (Dambach et al., 2006).

In large doses, AP is hepatotoxic causing oxidative stress and lipid peroxidation therefore; antioxidatants such as NAC have been used against the hepatic toxicity of AP. The present study aimed at declaring the possible protective effect of PTX (being antioxidant and anti-TNF- $\alpha$ ) on AP-induced hepatotoxicity in mice and to examine the effect of PTX on TNF- $\alpha$ and lipid peroxidation in this specific situation.

\section{MATERIALS AND METHODS}

Drugs used:

* Pentoxifylline (PTX) powder was purchased from Sigma CO.; it was dissolved in sterile isotonic saline solution.

* Paracetamol powder (N-acetyl-4 aminophenol; acetaminophen; AP) also was purchased from Sigma chemicals CO., USA. It was dissolved in sterile isotonic saline.

* $\mathrm{N}$-acetyl cysteine (NAC) was purchased from Sigma CO.

\section{Animals used :}

The present work was conducted on mice because of its greater susceptibility to the toxic effects of AP as compared to rats (Kuralay et al., 1998). The present study was carried out on 36 healthy male mice weighing 25-30 grams. All animals were kept under similar housing conditions. They were divided into 6 equal groups as follows: 
Group (I) : received intraperitoneally (IP) $0.5 \mathrm{ml}$ of normal saline (single dose).

Group (II) : received NAC in a single dose of $150 \mathrm{mg} / \mathrm{kg} \mathrm{IP,}$ (Sener et al., 2003).

Group (III) : received PTX in a single dose of $100 \mathrm{mg} / \mathrm{kg} \mathrm{IP,} \mathrm{(Re-}$ uter \&Wallace, 1999).

Group (IV): received AP in a single dose of $900 \mathrm{mg} / \mathrm{kg} \mathrm{IP,}$ (Sener et al., 2003).

Group (V): received NAC (in a single dose of $150 \mathrm{mg} / \mathrm{kg}$, IP), 30 minutes before IP injection of $900 \mathrm{mg} / \mathrm{kg} \mathrm{AP}$.

Group (VI): received PTX (in a single dose of $100 \mathrm{mg} / \mathrm{kg}$, IP), 30 minutes before IP injection of $900 \mathrm{mg} / \mathrm{kg} \mathrm{AP}$.

All the administered agents are given as a single dose. After 4 hours of administration knifing decapitated all the animals. Blood was collected and the serum samples were stored at $-70^{\circ} \mathrm{C}$. Liver tissues were carefully excised, and also stored at $-70^{\circ} \mathrm{C}$. Tissue samples were homogenized with ice-cold $150 \mathrm{mM} \mathrm{KCl}$ for determination of MDA levels. The following parameters were estimated:
* Serum alanine aminotransferase (ALT), utilizing Randox laboratories kits, UK (Schmidt and Schmidt, 1973).

* Serum TNF- $\alpha$ according to (Carti et al., 1992).

* Hepatic tissue malondialdehyde (MDA) was measured spectrophotometrically using the method of Beuge and Aust, (1978).

* Hepatic tissue calcium content was measured according to the method of Sparaw and Johnstone (1964).

\section{Statistical analysis:}

Statistical analysis was done using the computer system SPSS (statistical package for social science program; version 10). Student " $t$ " test according to Pipkins, (1984), was used to compare between each two means. A value of $p<0.05$ was considered statistically significant.

\section{RESULTS}

Serum ALT and TNF- $\alpha$ levels were increased significantly following treatment with $\mathrm{AP}$ in comparison to control group (Tab. 1, Figs. 1 \& 2). Intraperitoneal pretreatment with either NAC or PTX decreased significantly ALT and TNF- $\alpha$ levels but the levels were still higher than the control (Table, 1 and Figs. 1\&2). Liver tis- 
sue MDA (the end product of lipid peroxidation) and hepatic tissue calcium contents were significantly increased after IP administration of AP to the mice. Administration of either NAC or PTX intraperitoneally to mice, 30 minutes before injection of AP induced significant decrease of hepatic tissue MDA and calcium contents but the levels were still higher than the control (Table 2 \& Fig. 2).

\section{DISCUSSION}

In the present study, serum ALT and serum TNF- $\alpha$ significantly increased following AP treatment (Table 1 \& Figs. $1 \& 2)$. This rise in serum ALT demonstrates deterioration of liver function. Furthermore, in this model of AP-induced hepatic injury, we observed a significant increase in hepatic tissue MDA and calcium levels (Table 2 \& Fig. 3). These findings are in accord with Kernna et al., (2006). As they reported that oxidative stress plays an important role in APinduced hepatotoxicity. In addition to inducing direct cellular damage, oxidants can activate transcription of factors including nuclear factor-kappa B (NF-KB), which regulates the production of many inflammatory mediators implicated in pathogenesis of hepatotoxicity. In the current study NAC as well as PTX pretreatment reduced AP-induced hepatotoxicity as documented from significantly decreased serum ALT. Furthermore, hepatic tissue MDA was restored to nearly control level (Table $1 \&$ Figs. 1\&3). This is because NAC is a known free radical Scavenger (Karbownik et al., 2001), the involvement of free radicals in the pathogenesis of APinduced hepatotoxic effect is supported by previous studies done by Shibanuna et al., (1994), Rahman et al., (1998), Zhou et al., (2004), and Sullivan et al., (2005). They have been demonstrated that TNF- $\alpha$ exerts its effects via (NF-KB) in various types of cells. TNF- $\alpha$ induced NF-KB activation suggested to be mediated by reactive oxygen intermediates such as hydrogen peroxides. In addition, pretreatment with NAC for $0.5 \mathrm{~h}$ inhibited TNF- $\alpha$ - induced generation of reactive oxygen species (ROS) as well as activation of NF- KB. NAC which is a sulfhydryl donor serving as a precursor of glutathione (GSH) synthesis and inhibiting formation of extra cellular reactive oxygen intermediates (Dobrzynska et al., 2000). Moreover, it may directly react with electrophilic compounds such as NAPQI and free radicals. As AP metabolism is related to reduced $\mathrm{GSH}$, at least part of the beneficial effects of NAC may be ascribed to the inhibition of lipo- peroxidative process. In addition, the antioxidant effect produced by PTX in this study is supported by the work of Kranse et al., (1991) and $\mathrm{Ng}$ et al., (2003), where they documented that PTX even in low doses $(50 \mathrm{mg} / \mathrm{kg}$ ) has been associated with suppression of neutrophil function such as chemotaxis, 
superoxide anion production, hydrogen peroxide production, phagocytosis and degranulation.

In the present study, AP-treated mice showed a significant increase in the hepatic tissue calcium (Table $2 \&$ Fig. 3). This result is supported by the work of Ota et al., (1995) as they proposed that alteration in calcium homeostasis played a major role in cell necrosis- induced by a variety of chemical agents including AP. Pretreatment with either NAC or PTX significantly decreased hepatic tissue calcium as compared to control groups. This finding could be explained on the light of the work conducted by Beatric et al., (1989). They reported that the intrahepatocytes calcium concentration is controlled by active transport of these ions across the mitochondria, endoplasmic reticulum and plasma membrane. The liver mitochondria are protected against high cytosolic $\mathrm{Ca}^{+2}$ levels by the presence of glutathione, but became permeable to calcium when oxidative events convert GSH to oxidized glutathione ( $\mathrm{Li}$ et al., 1995). In the present study NAC and PTX improved intrahepatocyte calcium homeostasis secondary to their antioxidant activity achieved by significant decrease of hepatic tissue MDA (Table 2 \& Fig. ). These results also supported by the study of Anderson et al., (2005), where they demonstrated that oxidative stress provokated by alteration of hepatocyte calcium homeostasis played a major role in cell necrosis occurs in ischemia reperfusion injury.

Furthermore, the current work showed that the level of TNF- $\alpha$ was significantly increased following AP dosing (Table 1 \& Fig. 2), suggesting that TNF- $\alpha$ may be involved in liver injury elicited by AP overdose. These data corroborated by Blazka et al., (1995), they demonstrated that TNF- $\alpha$ played a role in AP-induced hepatotoxicity. In addition, Nagai et al., (2002), reported that reduced glutathione depletion causes necrosis and sensitization to tumor necrosis factor- $\alpha$ - induced apoptosis in cultured mouse hepatocytes. On the other hand, Boess et al., (1998) and Simpsn et al., (2000), have suggested that TNF- $\alpha$ is not involved in AP-induced liver injury because both TNF- $\alpha$ - knock out mice and wild type are equally susceptible to APinduced toxicity. Also the inhibition of TNF- $\alpha$ activity fails to attenuate the liver injury elicited by AP.

On the light of the present study it could be concluded that PTX produced a prophylactic effect against acetaminophen-induced liver injury in mice. This is due to its antioxidant and anti- TNF- $\alpha$ effects. The action of PTX was comparable to the prophylactic effect of NAC in such condition. We are in need to further experimental studied on other different animal species and also human studies especially on those with normal liver functions. 
Table (1): Changes in serum alanine aminotransferase (ALT) and tumor necrosis factor alpha (TNF- $\alpha$ ) in various groups. Mean \pm SEM. $(n=6$ mice/group):

\begin{tabular}{|c|c|c|c|c|c|c|}
\hline Parameter & $\begin{array}{c}\text { Group (I) } \\
\text { Control } \\
\text { (0.5 ml } \\
\text { saline, IP) }\end{array}$ & $\begin{array}{c}\text { Group (II) } \\
\text { NAC } \\
\text { treated } \\
(150 \mathrm{mg} / \mathrm{kg} \\
\text { /IP) }\end{array}$ & $\begin{array}{c}\text { Group (III) } \\
\text { PTX } \\
\text { treated } \\
(100 \mathrm{mg} / \mathrm{kg} \\
\text { IP) }\end{array}$ & $\begin{array}{c}\text { Group }(\mathrm{IV}) \mathrm{AP} \\
\text { treated } \\
(900 \mathrm{mg} / \mathrm{kg} / \mathrm{IP})\end{array}$ & $\begin{array}{c}\text { Group (V) } \\
\text { NAC (150 } \\
\text { mg/kg, } 30 \\
\text { minutes } \\
\text { before IP } \\
900 \text { mg AP) }\end{array}$ & $\begin{array}{c}\text { Group (VI) } \\
\text { PTX (100 } \\
\text { mg/kg, } 30 \\
\text { minutes } \\
\text { before IP } \\
900 \mathrm{mg} / \mathrm{kg} \\
\text { AP) }\end{array}$ \\
\hline $\begin{array}{c}\text { Serum ALT } \\
\text { (IU/ml) }\end{array}$ & $11.5 \pm 0.2$ & $11.9 \pm 0.4$ & $11.8 \pm 0.3$ & $750 \pm 8.6^{\bullet}$ & $75.3 \pm 4.6^{*}+^{+}$ & $98.8 \pm 6.3 \bullet \bullet$ \\
\hline $\begin{array}{l}\text { TNF- } \alpha \\
(\mathrm{Pg} / \mathrm{ml})\end{array}$ & $0.95 \pm 0.02$ & $0.97 \pm 0.06$ & $0.98 \pm 0.03$ & $4.5 \pm 0.04 \bullet$ & $1.2 \pm 0.01^{*}$ & $1.8 \pm 0.05 \cdot \bullet+$ \\
\hline
\end{tabular}

$\mathrm{SEM}=$ Standard error of mean.

; $\mathrm{P}$ value is significant $(<0.05)$ between AP treated and control group.

*; $\mathrm{P}$ value is significant $(<0.05)$ between $(\mathrm{NAC}+\mathrm{AP})$ group and (AP) group

$+^{+} \mathrm{P}$ value is significant $(<0.05)$ between $(\mathrm{NAC}+\mathrm{AP})$ and $(\mathrm{NAC})$ groups.

••; P value is significant $(<0.05)$ between $(\mathrm{PTX}+\mathrm{AP})$ and $(\mathrm{AP})$ groups.

+ ; $\mathrm{P}$ value is significant $(<0.05)$ between $(\mathrm{PTX}+\mathrm{AP})$ and $(\mathrm{PTX})$ groups.

NAC $:=\mathrm{N}$-acetylcysteine

PTX $=$ Pentoxifylline

$\mathrm{AP}=$ acetaminophen 
Table (2): Changes in hepatic tissue calcium and malondialdehyde (MDA) in various groups.

Mean \pm SEM. ( $n=6$ mice/group):

\begin{tabular}{|c|c|c|c|c|c|c|}
\hline Parameter & $\begin{array}{c}\text { Group (I) } \\
\text { Control } \\
\text { (0.5 ml } \\
\text { saline, IP) }\end{array}$ & $\begin{array}{c}\text { Group (II) } \\
\text { NAC } \\
\text { (150mg/kg } \\
\text { (IP) }\end{array}$ & $\begin{array}{c}\text { Group } \\
\text { (III) PTX } \\
(100 \mathrm{mg} / \mathrm{kg} \\
\text { /IP) }\end{array}$ & $\begin{array}{c}\text { Group (IV) } \\
\text { AP } \\
(900 \mathrm{mg} / \mathrm{kg} / \mathrm{IP})\end{array}$ & $\begin{array}{c}\text { Group (V) } \\
\text { NAC (150 } \\
\text { mg/kg, IP } \\
\text { before AP } \\
(900 \mathrm{mg} / \mathrm{kg} \\
\text { IP) }\end{array}$ & $\begin{array}{c}\text { Group (VI) } \\
\text { PTX (100 } \\
\text { mg/kg, IP, } 30 \\
\text { minutes before } \\
\text { AP (900 mg/kg } \\
\text { IP) }\end{array}$ \\
\hline $\begin{array}{l}\text { Hepatic } \\
\text { tissue } \\
\text { MDA } \\
\text { (nmol/gm } \\
\text { tissue) }\end{array}$ & $1.4 \pm 0.001$ & $1.5 \pm 0.002$ & $0.99 \pm 0.001$ & $3.7 \pm 0.03 \bullet$ & $1.99 \pm 0.005^{*}+$ & $2.1 \pm 0.01+\bullet \bullet$ \\
\hline $\begin{array}{l}\text { Hepatic } \\
\text { tissue } \\
\mathrm{Ca}+2(\mathrm{mg} / \mathrm{g} \\
\mathrm{m} \text { tissue) }\end{array}$ & $0.99 \pm 0.002$ & $0.98 \pm 0.001$ & $0.88 \pm 0.001$ & $3.8 \pm 0.01$ • & $1.9 \pm 0.03^{*+}$ & $2.1 \pm 0.02+\bullet \bullet$ \\
\hline
\end{tabular}

$\mathrm{SEM}=$ Standard error of mean.

-; P value is significant $(<0.05)$ between AP treated and control group.

*; P value is significant $(<0.05)$ between $(\mathrm{NAC}+\mathrm{AP})$ group and $(\mathrm{AP})$ group

$+^{+:} \mathrm{P}$ value is significant $(<0.05)$ between $(\mathrm{NAC}+\mathrm{AP})$ and $(\mathrm{NAC})$ groups.

•; P value is significant $(<0.05)$ between $(\mathrm{PTX}+\mathrm{AP})$ and $(\mathrm{AP})$ groups.

+ ; $\mathrm{P}$ value is significant $(<0.05)$ between $(\mathrm{PTX}+\mathrm{AP})$ and $(\mathrm{PTX})$ groups.

$\mathrm{NAC}=\mathrm{N}$-acetylcysteine

PTX= Pentoxifylline

$\mathrm{AP}=$ acetaminophen 


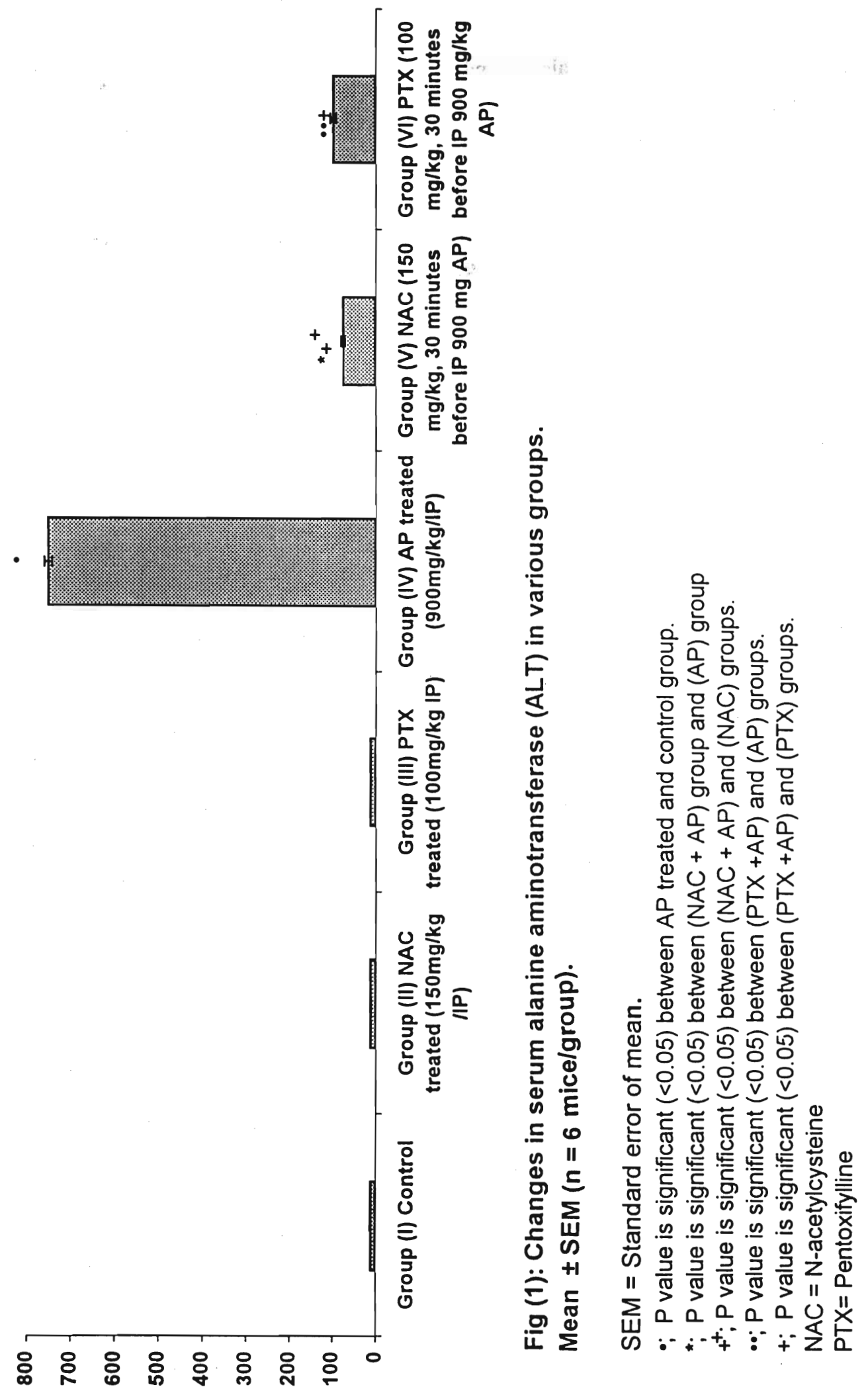

Mansoura J. Forensic Med. Clin. Toxicol. 
Mokbel, S. A.

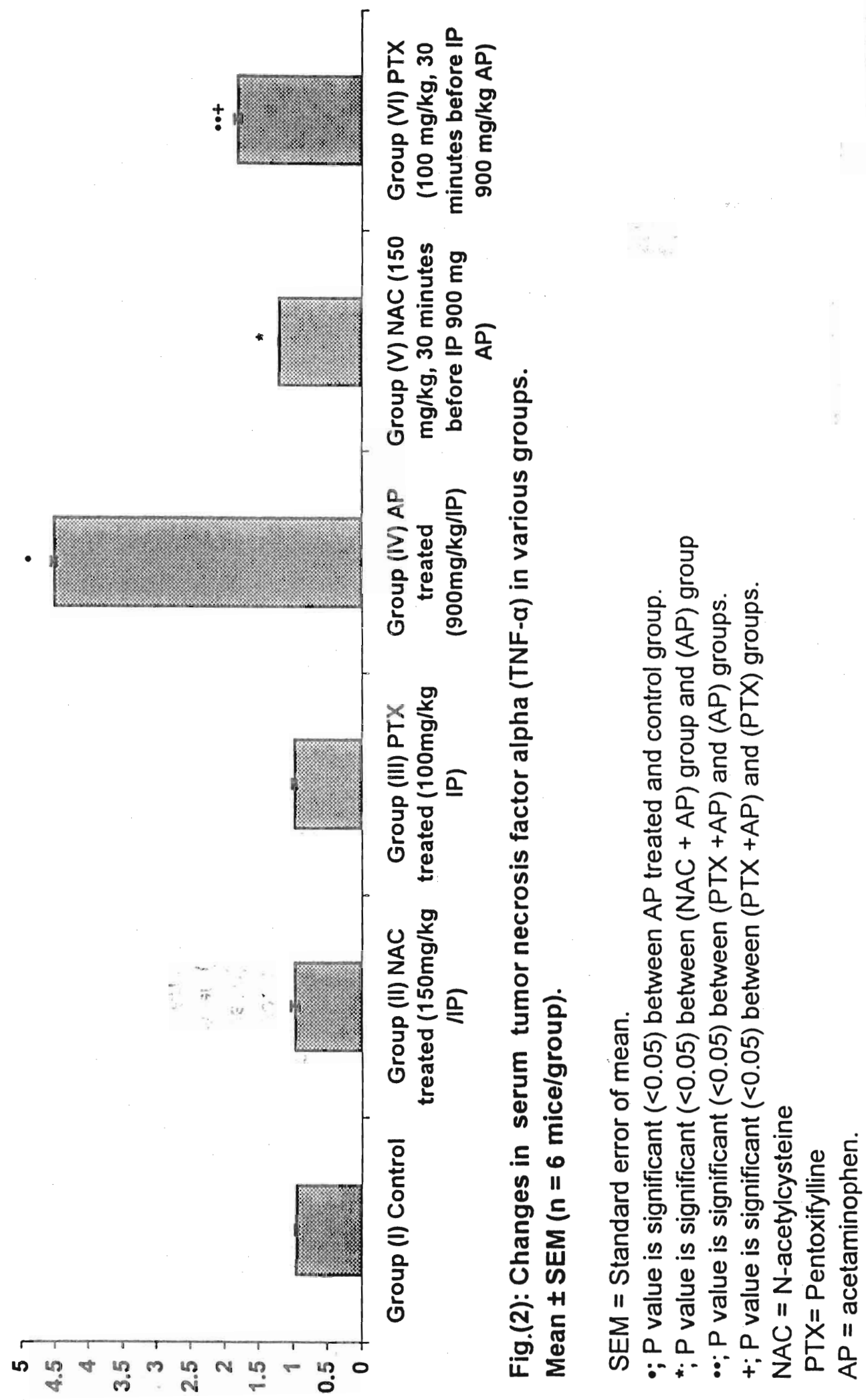


Mokbel, S. A.

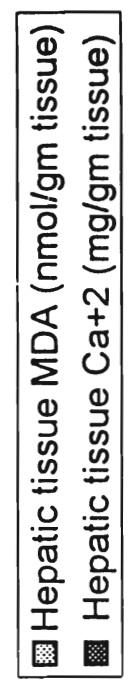

음

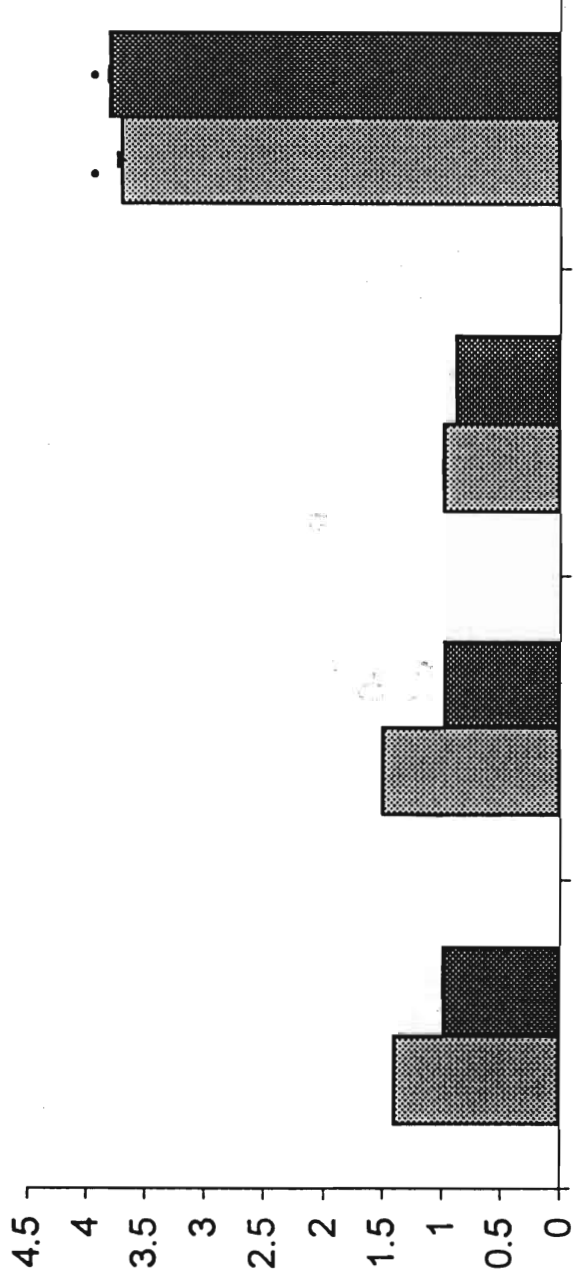

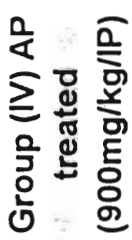

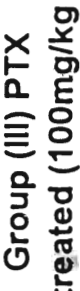

동요

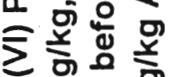

을 घे

인을을 응

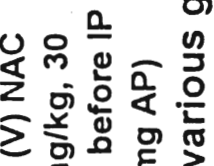

O $E$ \&

它色突

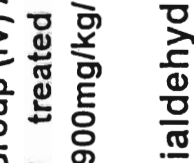

$\frac{0}{\frac{0}{0}}$

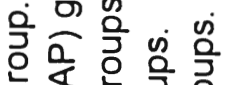

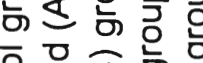

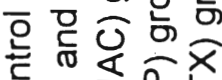

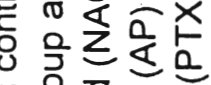

प्र

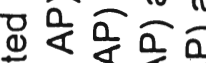

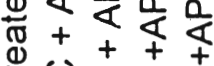

눈

定之否㔯占

Ф

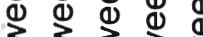

号紊

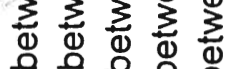

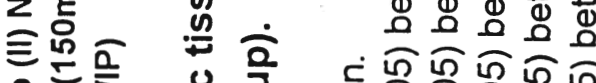

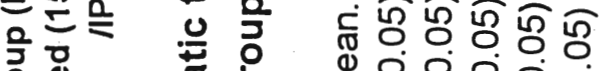

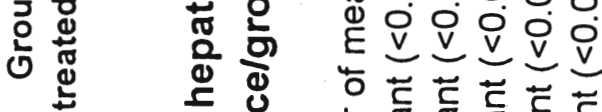

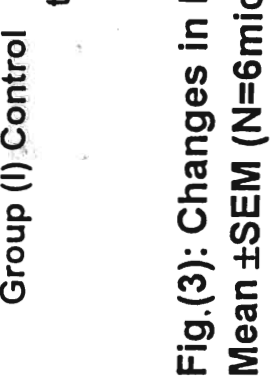

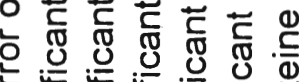

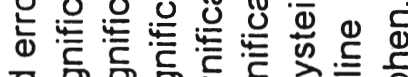

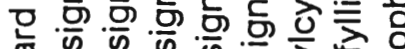

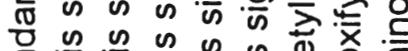

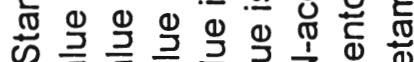

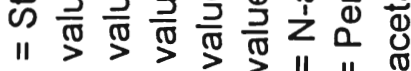

$\sum a 0 a 0$ व

岕:..+

Mansoura J. Forensic Med. Clin. Toxicol.

Vol. XII No. 2, July 2005 


\section{REFERENCES}

Anderson, C.; Pierce, J.; Nicourd, J.; Belons, A. and Knox, C. (2005) : "Modulation of mitrochondrial calcium management attenuates hepatic warm ischemia reperfusion injury". Liver Transpl., 11:663.

Beatric, M.; Stiers, D. and Pfeiffer, D. (1989) : "Role of hepatocyte calcium homeostasis in acetaminophen- induced liver toxicity". J. Biol. Chem., 259:1279.

Beuge, J. and Aust, S. (1978) : "Microsomal lipid peroxidation". Methods Enzymol., 52:302.

Blazka, M.; Wilmer, J.; Holladay, S.; Wilson, R. and Luster, M. (1995) : "Role of proinflammatory cytokines in acetaminophen hepatotoxicity". Toxicol. Appl. Pharmacol., 133:43.

Boess, F.; Bopst, M.; Althaus, R.; Polsky, S.; Cohen, S.; Eugster, H. and Boelsterli, U. (1998) : "Acetaminophen hepatotoxicity in tumor necrosis factor / lymphotoxin alpha gene knock out mice". Hepatology, 27:1021.

Carti, A.; Fassina, G.; Marcucci, F.; Barbannti, E. and Cassani, G. (1992) : "Oligomeric tumor necrosis factor (Slowly convents to inactive forms of bioactive)". Biochem. J., 284: 165.
Dambach, D.; Durham, S.; Laskin, J. and Laskin, D. (2006) : "Distinct roles of NF-Kappa B in the regulation of acetaminophen-induced inflammatory mediators and hepatotoxicity". Toxicol. Appl. Pharmacol., 211:157.

Dobrzynska, I.; Skrzydlewska, E.; Kasacka, I. and Figaszewski, Z. (2000) : "Protective effect of $\mathrm{N}$-acetylcysteine on rat liver cell membrane during methanol intoxication". J. Pharm. Pharmacol., 52:547.

Gomez-Cambronero, L.; Camps, B.; Suncion, T.; Cerda, M.; Pellin, A. and Pallardof, (2000) : "Pentoxifylline ameliorates cerulean-induced pancreatitis in rats: Role of glutathione and nitric oxide". J. pharmacol. Exp. Therap., 18:670.

Karbownik, M.; Lewinski, A. and Peiter, R. (2001) : "Anti- carcinogenic actions of melatonin which involve anti- oxidative processes: comparison with other antioxidants". Int. J. Biochem. Cell Biol., 33:735.

Kernna, S.; Tomizawa, A.; Hiura, T.; Osanaiy, Y.; Katuta, M.; Kitajima, Y.; Koiwaik, Ohtake, T.; Ujibe, M. and Ischikaura, M. (2006) : "Melatonin protects on toxicity by acetaminophen but not on pharmacological effect in mice". Biol. Pharm. Bull., 29:472.

Krahauer, T. (2000) : "Pentoxifylline inhibits ICAM-1 expression and chemokine 
production by proinflammatory and cytokines in human pulmonary epithelial cells". Immunopharmacology, 46:253.

Kranse, P.; Maderazo, E. and Contrino, J. (1991) : "Modulation of neonatal neutrophil function by pentoxifylline". Pediatr. Res., 9:123.

Kuralay, F.; Akarca, U.; Ozutemiz, A.; Kutay, F. and Batur, Y. (1998) : "Possible role of glutathione in prevention of acetaminophen- induced hepatotoxicity enhanced by fish oil in male Wister rats". J. Toxicol. Environ. Health, 53:223.

Li, D.; Lu, H.; Li, X. and Quan, Q. (1995) : "Hepatic tissue calcium Glutathione relationship". Chin. Med. J. (Engl), 108:903.

Mah, M.; Aebehard, E. and Gilliam, M. (1993) : "Effects of pentoxifylline on vivo leukocyte function and clearance of group B- streptococcal disease". Immun., 62:4997.

Maksymowych, W.; Avina-Zubieta, A.; Luong, M. and Russell, A. (1995) : Study of pentoxifylline in the treatment of severe refractory rheumatoid arthritis.

Nagai, H.; Matsumaru, K.; Feng, G. and Kaplowitz, N. (2002) : "Reduced glutathione depletion causes necrosis and sensitization to tumor necrosis factor- al- pha induced apoptosis in cultured mouse hepatocytes". Hepatology, 36:55.

Ng, P.; Lik-Wong, R.; Chui, K.; Wong, E.; Li, G. and Fok, T. (2003) : "Proinflammatory and anti-inflammatory cytokine responses in preterm infants with systemic infections". Arch. Child. Fetal Neonatal, 88:209.

Ota, K.; Shjo, H.; Kokawa, H. and Kubara, K. (1995) : "Calcium homeostasis plays a major role in cell necrosis-induced by acetaminophen". J. Gastroenterol. Hepatol., 10:198.

Pipkins, F. B. (1984) : Statistical analysis of the obtained data; descriptive and comparative analysis In : Medical Statistical Made Ease, Churchill Living Stone Publications, London, Melbourne, New York.

Rahman, A.; Kefer, J.; Bando, M.; Niles W. and Malik, A. (1998) : "E-Selectin expression in human endothelial cells by TNF- $\alpha$-induced oxidant generation and NF-KB activation". Am. J. Physiol.,275:533.

Reuter, B. and Wallace, J. (1999) : "Phosphodiesterase inhibitors prevent non-steroidal anti-inflammatory drug enteropathy independently of effects on tumor necrosis factor-alpha release". Am. J. Physiol. Gastrointestinal Liver Physiol., 277:847. 
Schmidt, E. and Schmidt, F. (1973) : "Calorimetric determination of GPT". Enzyme Biol. Clin., 3:1.

Semmler, J.; Gerbert, U.; Eisenhut, T.; Molders, J. and Schonharting, M. (1993) : "Xanthine derivatives: Comparison between suppression of tumor necrosis factor-alpha production and inhibition of cAMP phosphodiesterase activity". Immunology, 78:520.

Sener, G.; Sphirli, A. and Dulger, G. (2003) : "Protective effects of melatonin, vitamin $\mathrm{E}$ and $\mathrm{N}$ - acetylcysteine against acetaminophen toxicity in mice a comparative study". J. Pineal Res., 35:61.

Shibanuna, M.; Kuroki, T. and Nose, K. (1994) : Inhibition of by N-acetyl-L cysteine of interleukin- $6 \mathrm{~m}$ RNR induction and activation of nuclear factor kappa- $B$ by tumor necrosis factor-alpha in a mouse fibroblastic cell line, Balb/3T3". FEBS. Lett., 353:62.

Simpsn, K.; Lukacs, N.; Gregor, A.;
Harrison, D; Strieter, R. and Kunkel, S. (2000) : "Inhibition of tumor necrosis factor- alpha doesn't prevent experimental paracetamol- induced hepatic necrosis". J. Pathol., 190:489.

Sparaw, M. and Johnstone, B. (1964) : "A rapid micro- method of extraction of $\mathrm{Ca}^{2+}$ and $\mathrm{Mg}^{2+}$ from tissue". Biochem. Biophys. Acta., 90:425.

Sullivan, D.; Ferris, M.; Poiask, D. and Brody, A. (2005): "Tumor necrosis factor alpha induces transforming growth factor-beta-1 expression in lung fibroblasts through the extra-cellular signal-regulated kinase pathway". Am. J. Respire. Cell Mol. Biol., 32 : 342.

Zhou, Z.; Wong, L.; Song, Z. and Saari, J. (2004) : "Abrogation of nuclear factor kappa- B activation is involved in zinc inhibition of lipopolysaccharideinduced tumor necrosis factor-alpha production and liver injury". Am. J. Pathology, 164:1547. 


\title{
دراسة تأثير دواء البنتوكسيفلين على السُمية الكبدية الهحدثة معهملياً بالاسيتا مينوفين فى الجرذان البيضاء
}

\author{
المشتركون فى البحث \\ د.سو ميه عبداللطيف مقبل \\ قسم الفارماكولوجى - كلية الطب - جامعة المنصورة
}

أجرى هذا البحث لدراسة إحتـال وجود أثر وقائى لدواء البنتوكسيفلين بالمقارنة بدواء إنأستيل - سستين على السُمية الكبدية المحدثة معملياً فى الجرذان البيضا ء بواسطة دواء الاسيتامينومين.

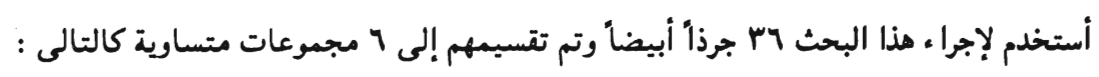

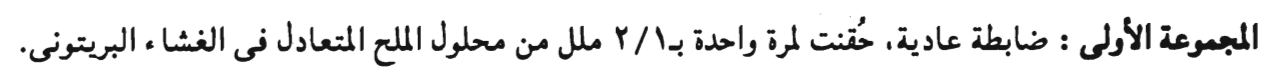

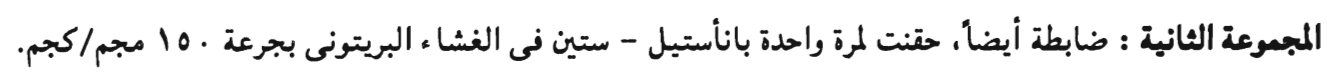

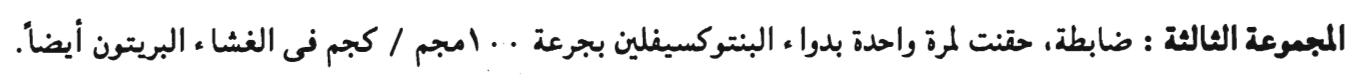

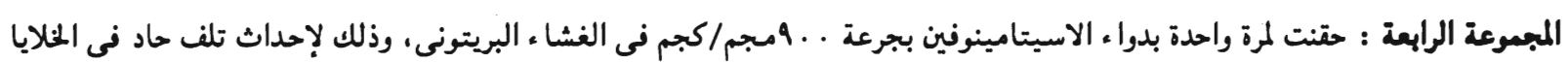
الكبدية.

المجموعة المامسة : حقنت لمرة واحدة بانأستيل - سستين بنفس الطريقة والجرعة السابقة وذلك قبل حقن . . ومجم/كجم من الاسيتامينوفين بمدة · r ب دقيقة وذلك لمرة واحدة.

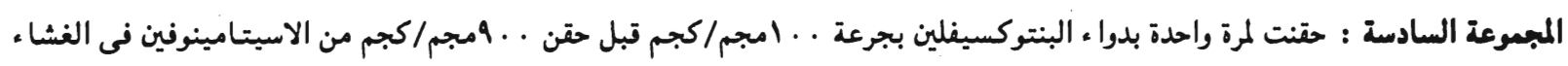

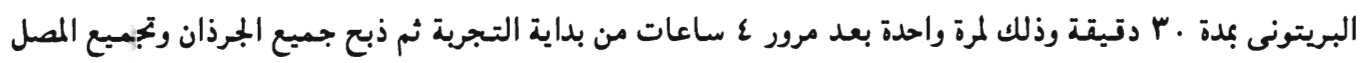

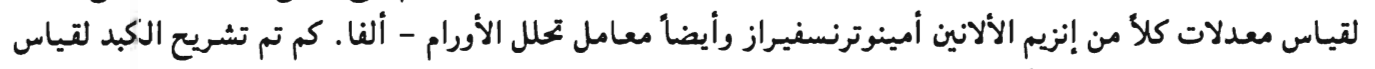

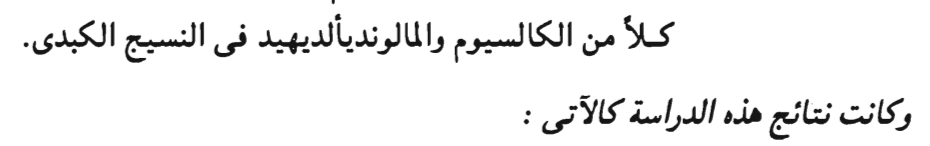

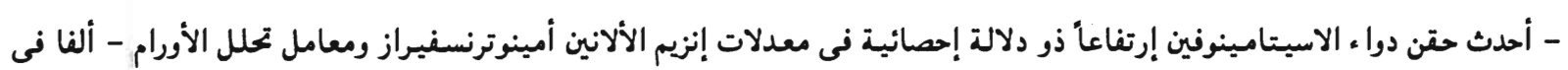

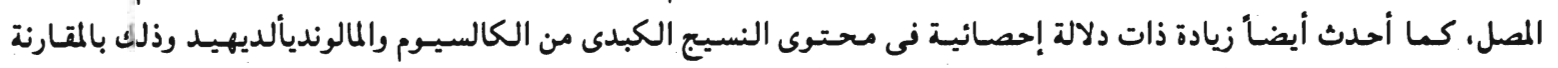

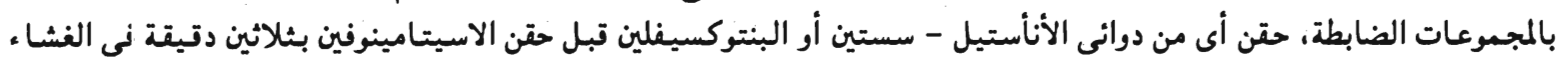

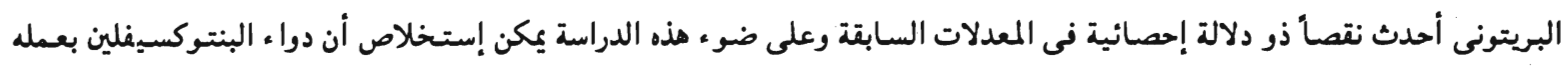

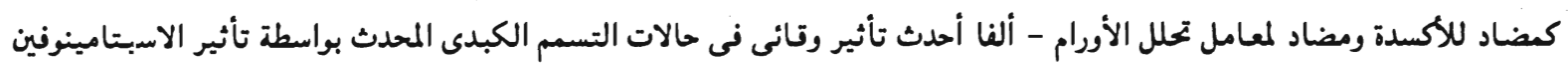

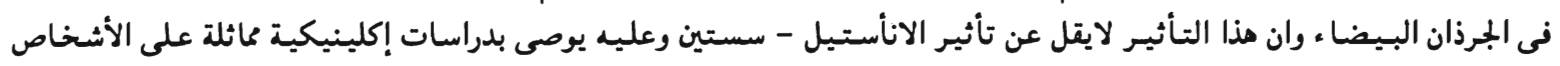

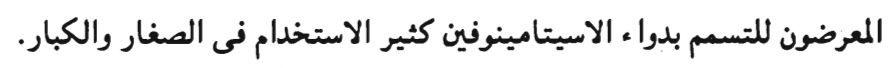

Mansoura J. Forensic Med. Clin. Toxicol.

Vol. XII No. 2, July 2005 